Borralho, N. M. G., P. P. Cotterill and P. J. Kanowski (1992): Genetic control of growth of Eucalyptus globulus in Portugal: II., Efficiencies of early selection. Silvae Genetica 41: 70-77.

Botelho, F. B. S., M. A. P. Ramalho, A. De F. B. Abreu, H. J. A. Rosa (2011): Multiline as a strategy to reduce damage caused by Colletotrichum lindemuthianum in common bean. Journal of Phytopathology, 159: 175-180.

Bruzi, A. T., M. A. P. Ramalho, A. F. B. Abreu, D. F. Ferreira and M. R. SenA (2007): Homeostasis in bean population with different genetics structures. Crop Breeding and Applied Biotechnology 7: 111-116.

Federer, W. T., J. C. Connigale, J. N. Rutger and A. WiJESINHA (1982): Statistical analyses of yields from uniblends and biblends of eight dry bean cultivars. Crop Science 22: 111-115.

Helland, S. J. and J. B. Holland (2001): Blend response and stability and cultivar blending ability in oat. Crop Science 41: 1689-1696.

Massaro, R. A. M., C. A. V. Bonine, E. A. Scarpinati and R. C. DE PAUlA (2010): Viabilidade de aplicação da seleção precoce em testes clonais de Eucalyptus spp. Ciência Florestal 20: 597-609.

Mastrantonio, J. J. S., I. F. Antunes, E. P. Zonta, B. M. Emygdio, C. Costa, L. Lobato, S. D. dos A. Silva and E. P. Silveira (2004): Interferência em misturas de feijão. Ciência Rural 34: 373-377.

Mille, B. and B. JouAN (1997): Influence of varietal associations on the development of leaf and glume blotch and brown leaf rust in winter bread wheat. Agronomie 17: 247-251.
NATional ACADEMy of ScIEncEs (1972): Genetic vulnerability of major crops. National Academy of Sciences/ National Research Council, Washington D.C.

Pereira, A. B., O. G. Marques Júnior, M. A. P. Ramalho and P. Althoff (1997): Eficiência da seleção precoce em famílias de meios irmãos de Eucalyptus camaldulensis Dehn, na região noroeste do Estado de Minas Gerais. Cerne 3: 67-81.

Pimental-Gomes, F. (2009): Curso de estatística experimental. $15^{\mathrm{a}}$ Ed. FEALQ, Piracicaba.

R Development Core Team (2010): R: a language and environment for statistical computing. R Foundation for Statistical Computing, Vienna.

Rezende, G. D. S. P., F. L. G. Bertolucci and M. A. P. RAMALHO (1994): Eficiência da seleção precoce na recomendação de clones de eucalipto avaliados no norte do Espírito Santo e sul da Bahia. Cerne 1: 45-50.

Silva, V. M. P., M. A. P. Ramalho, A. DE F. B. Abreu and F. B. Silva (2007): Estimation of competition parameters in common bean plants. Crop Breeding and Applied Biotechnology 7: 360-366.

Steel, R. G. D., J. H. Torrie and D. A. Dickey (1997): Principles and procedures of statistics: a biometrical approach. McGraw-Hill Book, New York.

Tolfo, A. L. T., R. C. De Paula, C. A. V. Bonine, A. Bassa and C. F. DO VALLE (2005): Parâmetros genéticos para caracteres de crescimento, de produção e tecnológicos da madeira em clones de Eucalyptus spp. Scientia Forestalis 67: 101-110.

\title{
Hybridizing ability and heterosis between Eucalyptus urophylla and $E$. tereticornis for growth and wood density over two environments
}

\author{
By Q. WenG ${ }^{1), 2)}$, X. $\mathrm{HE}^{2), 3)}, \mathrm{F} . \mathrm{LI}^{2)}, \mathrm{M} . \mathrm{LI}^{2)}, \mathrm{X} . \mathrm{YU}^{2)}$, J. SHI ${ }^{3)}$ and S. GAN ${ }^{\left.1,2),{ }^{*}\right)}$ \\ Q. WENG and X. HE equally contributed to this work
}

(Received $3^{\text {rd }}$ April 2013)

\begin{abstract}
Interspecific hybrids of Eucalyptus urophylla $\times$ E. tereticornis in a factorial-mating design were used to analyze general hybridizing ability $(G H A)$, specific hybridizing ability (SHA) and heterosis for height $(H$;

1) State Key Laboratory of Tree Genetics and Breeding, Chinese Academy of Forestry, Xiangshan Road, Beijing 100091, China.

$\left.{ }^{2}\right)$ Research Institute of Tropical Forestry, Chinese Academy of Forestry, Longdong, Guangzhou 510520, China.

$\left.{ }^{3}\right)$ The Key Laboratory of Forest Genetics and Biotechnology of Ministry of Education, Nanjing Forestry University, 159 Longpan Road, Nanjing 210037, China.

*) Corresponding author: Siming Gan. Tel. +86-20-87032402, Fax +86-20-87031622. E-Mail: Siming.Gan@ritf.ac.cn
\end{abstract}

$0.5,1.5,2.5,4$ and 7.5 years in age), diameter at breast height $(D$; ages 1.5, 2.5, 4 and 7.5) and wood density (WD; age 7.5) across two environments. The GHA variances were significant for all traits, and those of the SHA were also significant for most of the traits but with less magnitude, indicating the greater importance of additive gene effects in explaining the phenotypic variation among hybrids. The narrow-sense heritability $\left(h^{2}\right)$ and dominance $\left(d^{2}\right)$ estimates with hybrid growth and wood density ranged between $0.02 \pm 0.05\left(d^{2}\right.$ in $\left.D_{7.5}\right)$ and $0.23 \pm 0.10\left(d^{2}\right.$ in $\left.H_{1.5}\right)$ over the different ages, suggesting weak additive and dominant effects on these traits. Additive genetic correlations of growth with wood density were weak at age 7.5. Female general combining ability $(G C A)$ based on maternal open-pollinated families was not necessarily a good indicator of $G H A$ as their cor- 
relations were $0.48(P=0.17), 0.65(P=0.04)$ and -0.56 $(P=0.10)$ for $H_{75}, D_{75}$ and $W D_{75}$, respectively. A great proportion of hybrids showed positive female-parent heterosis $(F P H)$ at age 7.5 , with the highest relative $F P H$ of $47.2 \%$ in $D_{7.5}$. This study demonstrates the heterosis between inter-sectional species and could have implications for $E$. urophylla $\times E$. tereticornis hybrid breeding.

Key words: Hybridizing ability, heterosis, growth, wood density, Eucalyptus.

\section{Introduction}

The tree genus Eucalyptus L'HÉRIT (family Myrtaceae) comprises more than 780 species and subspecies of 10 subgenera (SLEE et al., 2006). Interspecific hybrids can often be readily produced, spontaneously or by manipulation, between closely related species within a subgenus, and hybrid superiority has been frequently observed in Eucalyptus (PoTTs and DUNGEY, 2004). With the technical progress in vegetative propagation, many Eucalyptus hybrids can be easily macro- (rooted cuttings) and/or micro-propagated (tissue culture), thereby enabling the utility of superior hybrid individuals for large-scale clonal cultivation (ELDRIDGE et al., 1993). In the past few decades, significant gains in productivity, uniformity and wood properties have been realized in eucalypts mostly due to the intensive plantation of hybrid clones. For example, the new hybrid varieties being planted largely in China are achieving an average wood yield of $20 \mathrm{~m}^{3} / \mathrm{ha}$ /year, almost three times that of the traditional species (BUEREN, 2004).

In quantitative genetics theory, the parental effects on hybrid performance could be analyzed by combining ability, including general and specific combining ability ( $G C A$ and $S C A$, respectively), in which $G C A$ is the average performance of a parent (line) in hybrid combinations and SCA represents the deviation in performance of a parental combination from the average expectation over the parents (lines) involved (SPRAGUE and TATUM, 1942; MelChinger and GuMBer, 1998). GCA is primarily a measure of additive genetic effects, which are amenable to selection, whereas $S C A$ includes non-additive effects (RoJAs and SPRAGUe, 1952). Thus, combining ability analysis is conducive to define the pattern of genetic effects influencing quantitative traits and identify potentially superior parents and hybrid combinations in breeding practices. Similarly, NIKLES and NEWTON (1991) proposed the concepts of general and specific hybridizing ability ( $G H A$ and $S H A$, respectively) to measure the parental additive and non-additive genetic effects, respectively, for interspecific hybrid crosses. So far, GHA and SHA have been evaluated in a number of forest tree taxa, e.g. European larch (Larix decidua MiLL.) and Japanese larch (L. kaempferi (LAMB.) CARR.) (PLÂQUES, 2004) as well as flooded gum (E. grandis HILL ex MAIDEN) and Timor mountain gum (E. urophylla S. T. BlAKe) (RETIEF and StANGER, 2009). Moreover, the correlation between GCA and GHA estimates, coupled with the magnitude of $S H A$, will provide fundamental information which can be used to optimize breeding strategies (Volker et al., 2008; RETIEF and STANGER, 2009).

The superior performance of hybrids over their parents or parental lines is defined as heterosis or hybrid vigor (SHULL, 1952). The phenomenon of heterosis has been widely exploited in plant breeding practices since its discovery at the beginning of the $20^{\text {th }}$ century (SHULL, 1908). In Eucalyptus, though hybrid depression was occasionally observed (e.g. E. nitens (DEANE and MAIDEN) MAIDEN $\times E$. globulus LABILl.; VolKer et al., 2008; Costa E Silva et al., 2012), heterosis has been demonstrated in economically important traits such as growth and processing characteristics as well as stress tolerance and resistance (e.g. MEDDINGS et al., 2001; GAN et al., 2004; HE et al., 2012a). Moreover, a number of approaches have been exploited to capture the heterosis for industrial plantations, such as mass production of $\mathrm{F}_{1}$ hybrid seed of heterotic parents (MARTIN, 1989) and mass clonal propagation of outstanding individuals (WATT et al., 1995). Thus far, great success in heterosis exploitation in Eucalyptus has been achieved in tropical and sub-tropical plantation forestry with the widespread use of $E$. urophylla $\times E$. grandis clones in South America, Asia and South Africa (GRIFFIn et al., 1988; PotTs and Dungey, 2004). However, the magnitude of heterosis and its underlying genetic mechanisms are poorly understood.

Eucalyptus trees are widely grown around the world for pulp production. Growth and wood density are very important traits in terms of pulp productivity per unit area. For such traits, several reports have estimated the $G H A$ and $S H A$ effects on inter-specific $\mathrm{F}_{1}$ hybrids of Eucalyptus, such as E. urophylla $\times E$. grandis for growth (Retief and Stanger, 2009) and E. nitens $\times$ $E$. globulus for both growth and wood density (VOLKER et al., 2008). However, the previous reports are based merely on single-site field trials, which may result in the environmental effects and thus biased the GHA and SHA estimates. Furthermore, the parental species analyzed previously are mostly of intra-sectional combinations, e.g. within sections Latoangulatae BROOKER (Retief and Stanger, 2009) and Maidenaria L. D. PryoR and L. A. S. Johnson ex Brooker (Volker et al., 2008) of subgenus Symphyomyrtus (SCHAUER) BROOKER according to the classification of BROOKER (2000). In this context, inter-sectional hybrids need to be examined in Eucalyptus for broadening the information on parental hybridizing ability as well as that of the magnitude of the observed heterosis.

Here we present the GHA, SHA and heterosis analyses in inter-sectional hybrids between $E$. urophylla and E. tereticornis SMITH (sections Latoangulatae and Exsertaria L. D. PrYor and L. A. S. Johnson ex Brooker under subgenus Symphyomyrtus, respectively; BROOKER, 2000) for growth and wood density over two environments. E. urophylla is native to Indonesia and East Timor while E. tereticornis is native to Australia and Papua New Guinea (ELDRIDGE et al., 1993). In addition to the favorable features of fast growth and versatile wood properties, the two species are favorably complementary in some other important traits. For instance, $E$. urophylla is characterized in early flowering (WU et al., 1996) and resistance to gall wasp (Leptocybe invasa FISHER and LA SALLE; THUA et al., 2009), and some provenances of $E$. tereticornis are advantageous in resistance to or tolerance of salinity (MARCAR, 1989), bacteri- 
al wilt (Ralstonia solanacearum SMITH; DIANESE and DRISTIG, 1993) and frost (LIN and LI, 2003). Thus, $E$. urophylla $\times E$. tereticornis hybrids may combine these characteristics and have great potentials in heterosis exploitation.

\section{Materials and Methods}

\section{Plant material}

A total of 62 crosses derived from an incomplete $10 \times 10$ factorial mating design of E. urophylla $\times$ E. tereticornis were used as per $\mathrm{HE}$ et al. (2012a), and 59 crosses were finally maintained while three died during the field trials. The parental trees were selected from previous provenance/family trials or seedling plantations as described earlier (HE et al., 2012b). Ten maternal open-pollinated (OP) families were also included, seeds of which were harvested from the maternal trees of the original trials or plantations.

\section{Field trial and trait measurement}

Seedlings of the crosses and OP families were field planted in July 2003 in two environments, namely, Yong'an County in northern Fujian Province (117 $23^{\prime}$ E, $25^{\circ} 53^{\prime} \mathrm{N}$ and $260-300 \mathrm{~m}$ above sea level) and Changtai County in southern Fujian (117 $52^{\circ} \mathrm{E}, 2^{\circ} 46^{\prime} \mathrm{N}$ and 225-260 $\mathrm{m}$ above sea level). The Yong'an trial site is relatively cold (mean annual temperature $18.7^{\circ} \mathrm{C}$ and absolute minimum $-7.0^{\circ} \mathrm{C}$ ) with deep soil, approximately 15 degree slope and annual rainfall $1564 \mathrm{~mm}$, whereas the Changtai site is warm (mean annual temperature $19.6^{\circ} \mathrm{C}$ and absolute minimum $-1.7^{\circ} \mathrm{C}$ ) with shallow red soil, about 20 degree slope and annual rainfall 1466 $\mathrm{mm}$. The field trial for all the crosses and OP families was set in a randomized complete block design with four replicates of four-tree row plots. Site preparation and tending operations were as described previously (HE et al., 2012a).

Measurements were made for height $(H, \mathrm{~m})$ at 0.5 , $1.5,2.5,4$ and 7.5 years of age, diameter at $1.3 \mathrm{~m}$ height $(D, \mathrm{~cm})$ at ages $1.5,2.5,4$ and 7.5 and wood density at age $7.5\left(W D_{7.5}\right)$. Wood density was indirectly measured by a bark-to-bark drilling of each standing tree at $1.3 \mathrm{~m}$ height using the Resistograph F-400S (Instrumenta Mechanik Labor GmbH, Wiesloch, Germany). The Resistograph system has been demonstrated to be reliable and efficient for assessing relative wood density of live trees in tree improvement programs (ISIK and LI, 2003). The Resistograph measurements were restricted to trees with $D_{7.5}$ greater than $8 \mathrm{~cm}$, and visible limbs and knots were avoided to eliminate outlier values. The average amplitude $(\%)$ of each measurement was calculated over the first $5 \mathrm{~cm}$ from the bark due to the increasing trend of resistance amplitude with the drilling depth (BoufFIER et al., 2008). The average amplitude was square-root transformed to a normal distribution for subsequent analyses.

\section{Statistical analyses}

For a given trait, the significance level of difference between hybrids and the maternal OP families was tested with $t$-test using Proc MEANS procedure in software
SAS/STAT ${ }^{\circledR} 6.0$ (SAS Institute Inc., Cary, NC, USA). A combined analysis of variance (ANOVA) was conducted based on plot means using Proc GLM in SAS/STAT ${ }^{\circledR} 6.0$ following the below mixed linear model:

$$
Y_{i j k}=\mu+G_{i}+E_{j}+R_{k}\left(E_{j}\right)+(G E)_{i j}+e_{i j k}
$$

where $Y_{i j k}$ is the trait value of the $i$ th genotype (hybrid or maternal open-pollinated family) in the $k$ th replication under the $j$ th environment, $\mu$ is an overall mean, $G_{i}$ is the effect of the $i$ th genotype, $E_{j}$ is the effect of $j$ th environment, $R_{k}\left(E_{j}\right)$ is the effect of the $k$ th replication within the $j$ th environment (fixed), $(G E)_{i j}$ is the genotype $\times$ environment interaction, and $e_{i j k}$ is the residual error. For the hybrid population, the genotype sum of squares was partitioned further into the variation due to female, male and female $\times$ male interaction. Proc VARCOMP (method REML) of SAS/STAT ${ }^{\circledR} 6.0$ was used to estimate the variance components. The variances due to female and male parents are equivalent to the $G H A$ effects, and the female $\times$ male interaction is equivalent to the $S H A$ effects, which are similar to the $G C A$ and $S C A$ effects, respectively, for intra-species hybrids (HALlAUER and MiRANDA, 1981).

Similar to the case of pure-species, narrow-sense heritability $\left(h^{2}\right)$ and dominance estimate $\left(d^{2}\right)$ were evaluated as:

$$
\begin{aligned}
h^{2}= & 2\left(\sigma_{G H A(F)}^{2}+\sigma_{G H A(M)}^{2}\right) / \sigma_{P}^{2} \\
d^{2}= & 4 \sigma^{2}{ }_{S H A} / \sigma_{P}^{2} \\
\sigma_{P}^{2}= & \sigma_{G H A(F)}^{2}+\sigma_{G H A(M)}^{2}+\sigma^{2}{ }_{S H A}+\sigma_{E}^{2}+ \\
& \sigma_{G H A(F) \times E}^{2}+\sigma_{G H A(M) \times E}^{2}+\sigma_{S H A \times E}^{2}+\sigma_{e}^{2}
\end{aligned}
$$

where $\sigma_{G H A(F)}^{2}, \sigma_{G H A(M)}^{2}, \sigma_{S H A}^{2}, \sigma_{E}^{2}, \sigma^{2}{ }_{G H A(F) \times E}, \sigma^{2}{ }_{G H A(M) \times E}$, $\sigma_{S H A \times E}^{2}, \sigma_{e}^{2}$ and $\sigma_{P}^{2}$ are the variance components of female $G H A$, male $G H A$, SHA, environment, female $G H A \times$ environment interaction, male $G H A \times$ environment interaction, $S H A \times$ environment interaction, error and total phenotype, respectively. Standard errors of $h^{2}$ and $d^{2}$ were estimated using the delta method ( $\mathrm{LYNCH}$ and WALSH, 1998).

Phenotypic $\left(r_{P}\right)$ and additive genetic $\left(r_{g}\right)$ correlation coefficients between traits across the two environments were estimated for the hybrid population using Proc MIXED (method REML) following the SAS code in APPENDIX C of HoLLAND (2006), modified by the deletion of SET effect from the related procedures. The additive genetic correlations were based on male covariance and covariance components derived from the mixed linear model mentioned above.

The estimates of maternal GCA $\left(G C A_{\mathrm{F}}\right)$, female $G H A$ $\left(G H A_{\mathrm{F}}\right)$, male $G H A\left(G H A_{\mathrm{M}}\right)$ and parental $S H A$ were generated with best linear unbiased predictors (BLUP) of individual family, female, male and hybrid, respectively, using Proc MIXED procedure (method REML) of SAS/STAT ${ }^{\circledR} 6.0$ based on plot means. For each hybrid, while mid-parent heterosis $(M P H)$ could not be estimated due to the absence of paternal OP families, absolute female-parent heterosis $(A F P H)$ and relative femaleparent heterosis $(R F P H)$ were calculated as follows:

$$
\begin{aligned}
& A F P H=Y_{i j}-Y_{i} \\
& R F P H=A F P H / Y_{i}
\end{aligned}
$$


Table 1. - Mean values of the traits measured for $E$. urophylla $\times E$. tereticornis hybrids and maternal open-pollinated (OP) families grown in two environments.

\begin{tabular}{|c|c|c|c|c|c|c|c|}
\hline \multirow[b]{2}{*}{ Trait } & \multirow[b]{2}{*}{ Environment } & \multicolumn{3}{|l|}{ Hybrid } & \multicolumn{3}{|c|}{ OP family } \\
\hline & & Mean & $\mathrm{CV}(\%)$ & $\operatorname{LSD}(5 \%)$ & Mean & $\mathrm{CV}(\%)$ & $\operatorname{LSD}(5 \%)$ \\
\hline \multirow[t]{3}{*}{$H_{0.5}(\mathrm{~m})$} & Yong'an & 0.75 & 41.2 & 0.40 & 0.76 & 50.8 & 0.29 \\
\hline & Changtai & 0.93 & 46.7 & 0.26 & 0.62 & 43.5 & 0.20 \\
\hline & Both & $0.84 * *$ & 44.9 & 0.26 & 0.69 & 45.9 & 0.18 \\
\hline \multirow[t]{3}{*}{$H_{1.5}(\mathrm{~m})$} & Yong'an & 5.56 & 25.1 & 1.89 & 5.08 & 39.3 & 1.56 \\
\hline & Changtai & 5.50 & 36.4 & 1.13 & 5.33 & 24,9 & 1,00 \\
\hline & Both & 5.53 & 29.7 & 1.19 & 5.21 & 30.5 & 0.93 \\
\hline \multirow[t]{3}{*}{$D_{1.5}(\mathrm{~cm})$} & Yong'an & 4.86 & 29.5 & 1.95 & 4.02 & 48.2 & 1.58 \\
\hline & Changtai & $4.43^{*}$ & 44.5 & 1.20 & 4.49 & 31.8 & 1.08 \\
\hline & Bolh & $4.64 *$ & 35.8 & 1.22 & 4.27 & 37.8 & 0,96 \\
\hline \multirow[t]{3}{*}{$H_{2.5}(\mathrm{~m})$} & Yong'an & 7.79 & 27.7 & 2.91 & 7.57 & 40.2 & 2.54 \\
\hline & Changtai & 8.61 & 33.6 & 1.97 & 6.83 & 32.3 & 1.78 \\
\hline & Both & $8.22 * *$ & 30.7 & 1.92 & 7.20 & 34.6 & 1.56 \\
\hline \multirow[t]{3}{*}{$D_{2,5}(\mathrm{~cm})$} & Yong'an & 9.16 & 21.4 & 2.93 & 6.74 & 44.6 & 2.59 \\
\hline & Changtai & $7.26 \%$ & 40.1 & 1.73 & 8.23 & 26.1 & 1.70 \\
\hline & Bolh & $8.17 *$ & 319 & 1.99 & 7.46 & 35.4 & 1.63 \\
\hline \multirow[t]{3}{*}{$H_{4}(\mathrm{~m})$} & Yong'an & 13.40 & 19.1 & 3.30 & 9.93 & 33.8 & 3.33 \\
\hline & Changtai & $11.11^{*}$ & 29.0 & 2.52 & 12.27 & 21.8 & 2,41 \\
\hline & Both & $12.15 * * *$ & 25.3 & 2.56 & 10.98 & 29.4 & 2.28 \\
\hline \multirow[t]{3}{*}{$D_{4}(\mathrm{~cm})$} & Yong'an & 10.73 ** & 26.6 & 3.80 & 8.58 & 43.5 & 3.57 \\
\hline & Changtai & 9.19 & 39.9 & 2.77 & 9.52 & 31.0 & 2.84 \\
\hline & Both & $9.89 *$ & 33.4 & 2.75 & 8.99 & 37.1 & 2.33 \\
\hline \multirow[t]{3}{*}{$H_{7.5}(\mathrm{~m})$} & Yong'an & 16.71 & 25.3 & 4.88 & 13.78 & 34.2 & 4.32 \\
\hline & Changtai & $14.68 *$ & 32.4 & 4.23 & 15.08 & 26.4 & 4.33 \\
\hline & Both & $15.62 \%$ & 28.4 & 3.80 & 14.36 & 29.9 & 3.00 \\
\hline \multirow[t]{3}{*}{$D_{7.5}(\mathrm{~cm})$} & Yong'an & 13.16 & 29.6 & 5.30 & 11.37 & 41.8 & 4.38 \\
\hline & Changtai & $12.06^{*}$ & 42.4 & 3.89 & 11.48 & 33.5 & 4.10 \\
\hline & Both & $12.57^{*}$ & 35.1 & 3.78 & 11.42 & 37.0 & 2.96 \\
\hline \multirow[t]{3}{*}{$W D_{7.5}\left(10^{\prime}\right)$} & Yong'an & 3.88 & 16.1 & 0.81 & 4.17 & 15.6 & 0.61 \\
\hline & Changtai & 4.29 & 17.6 & 0.64 & 3.65 & 15.0 & 0.63 \\
\hline & Both & 4.10 & 16.9 & 0.60 & 3.93 & 16.3 & 0.47 \\
\hline
\end{tabular}

$*$, ** and *** Significant in $t$-test at $0.05,0.01$ and 0.001 levels, respectively.

where $Y_{i j}$ is the mean of the hybrid between the $i$ th female and the $j$ th male parents, and $Y_{i}$ is the mean of $i$ th maternal OP family. As the female $E$. urophylla outperforms generally the male $E$. tereticornis in growth, $A F P H$ and $R F P H$ could be treated as the better-parent heterosis.

\section{Results}

\section{Mean performance}

For growth traits $H$ and $D$, the Yong'an environment showed generally higher mean values for hybrids but less means for maternal OP families as compared with
Changtai (Table 1). Also, the hybrid population outperformed consistently the OP progeny in growth after age 1.5 in Yong'an whereas the OP out-grew the hybrids in $H$ or $D$ over all ages in Changtai. However, coefficients of variation $(\mathrm{CV})$ for growth of both populations were large and ranged from $19.1 \%$ ( $H_{4}$ for hybrids in Yong'an) to $50.8 \%$ ( $H_{0.5}$ for OP progeny in Yong'an), indicating a wide variation in growth within each population. For wood density $W D_{75}$, similar contrasting pattern was observed for mean performance of the two populations between the two environments, that is, being higher with OP families in Yong'an but with hybrids in Changtai. 
Table 2. - Mean squares from the combined analyses of variances and the $h^{2}$ and $d^{2}$ estimates for 10 traits of the hybrids grown in two environments.

\begin{tabular}{|c|c|c|c|c|c|c|c|c|c|c|c|}
\hline Source & dl & $H_{05}$ & $H_{1.5}$ & $D_{1.5}$ & $H_{2.5}$ & $D_{2.5}$ & $\mathrm{H}_{4}$ & $D_{4}$ & $H_{7.5}$ & $D_{7.5}$ & $W D_{7.5}$ \\
\hline Environment (E) & 1 & 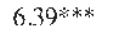 & 2.25 & 42.28 *䋖 & $211.11 \%$ & 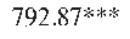 & 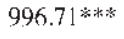 & 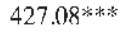 & $844.48 \cdots$ & $212.30^{* *}$ & 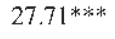 \\
\hline Replicate/E & 6 & 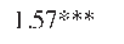 & $44.6 .3 * * * *$ & $42.24 * \approx$ 视 & $34.96^{*}$ & $35.09 * * *$ & 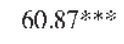 & $77.93 * * *$ & ] $04.49 \%$ & $119.46^{*} * *$ & $8.14 * * *$ \\
\hline Hybrid & 58 & $0.35^{* * * *}$ & $9.26^{* * * k}$ & $8.46^{* * \ldots}$ & $13.31^{*} * *$ & $14.27^{* * *}$ & $17.99^{*} *$ & 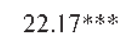 & $49.38^{* * * *}$ & $49.99^{* * *}$ & $1.03 * * * *$ \\
\hline$G H A_{1}$ & 9 & $0.52^{* * * * *}$ & $11.98^{* * * *}$ & $14.31^{* * * * *}$ & $19.16^{* * * * *}$ & $23.44^{* * * *}$ & $20.41^{*-k}$ & $31.17^{* \ldots * * * 2}$ & $51.32^{* * *}$ & $68.34^{* * *}$ & $0.74^{*}$ \\
\hline$G H \Lambda_{M 1}$ & 9 & 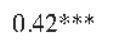 & $12.599^{* * * *}$ & $11.09^{* \ldots+1 / 2}$ & $12.71^{*}$ & $14.61^{\star \star *}$ & 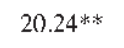 & $23.68^{*}$ & $31.80^{*}$ & $34.91 *$ & $1.06 *$ \\
\hline$S H A$ & 40 & $0.24^{\text {***;** }}$ & $5.48^{* * * *}$ & $4.91^{* * * * *}$ & $9.33 \%$ & $8.97^{* *}$ & $11.90^{*}$ & 12.62 & 23.94 & 20.87 & $0.57^{*}$ \\
\hline Hybrid $\times E$ & 56 & 0.16 & $3.95^{* * *}$ & $3.48^{*}$ & 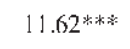 & $10.64: *$ & 9.53 & 9.77 & 25.13* & 23.05 & 0.40 \\
\hline$G H A_{\mathrm{L}} \times \mathbf{E}$ & 9 & 0.18 & $4.64^{*}$ & $5.6 L^{*}$ & $15.75^{* * w}$ & $12.30^{*}$ & 7.23 & 13.25 & 30.66 & 30.41 & 0.22 \\
\hline$G H A_{\mathrm{M}} \times \mathrm{E}$ & 9 & 0.16 & 4.14 & 2.62 & 7.75 & $10.38 \%$ & 11.10 & 6.50 & 31.04 & 25.79 & 0.41 \\
\hline$S H A \times \mathrm{E}$ & 38 & 0.15 & 3.24 & 3.24 & $9.32 \%$ & 7.41 & 8.08 & 6.10 & $27.34^{*}$ & 20.76 & 0.35 \\
\hline Pooled ertor & $-a$ & 0.13 & 2.40 & 2.44 & 5.75 & 5.38 & 7.61 & 9.81 & 17.53 & 18.16 & 0.40 \\
\hline$h^{2}$ estimate & & $0.07 \pm 0.05$ & $0.15 \pm 0.09$ & $0.11 \pm 0.07$ & $0.09 \pm 0.05$ & $0.11 \pm 0.06$ & $0.10 \pm 0.06$ & $0.12 \pm 0.06$ & $0.13 \pm 0.06$ & $0.17 \pm 0.07$ & $0.11 \pm 0.07$ \\
\hline$d^{2}$ estimate & & $0.17 \pm 0.07$ & $0.23 \pm 0.10$ & $0.22 \pm 0.09$ & $0.07 \pm 0.06$ & $0.11 \pm 0.07$ & $0.09 \pm 0.07$ & $0.07 \pm 0.06$ & $0.09 \pm 0.07$ & $0.02 \pm 0.05$ & $0.13 \pm 0.07$ \\
\hline
\end{tabular}

$*$, ** and *** Significant at $0.05,0.01$ and 0.001 levels, respectively.

a Value of df for pooled error varied with trait from 900 in $W D_{7.5}$ to 1228 in $H_{0.5}$.

When averaged over both environments, hybrids had consistently better performance than the OP families in all the traits studied, and their differences were significant in $t$-test except for $H_{1.5}$ and $W D_{7.5}$ (Table 1). $C V$ val- ues were relatively high for growth traits $H$ and $D$ (25.3-45.9\%) over all ages as compared with that of $W D_{7.5}$ (16.9\% for hybrids and $16.3 \%$ for OP families). The hybrids showed smaller $C V$ s exclusively in growth

Table 3. - Phenotypic correlations ( $r_{p}$, above the diagonal) and additive genetic correlations $\left(r_{g}\right.$, below the diagonal) between traits of growth and wood density at age 7.5.

\begin{tabular}{llll}
\hline Trail & $H_{7.5}$ & $D_{7.5}$ & $W D_{7.5}$ \\
\hline$H_{7.5}$ & & $0.86 \pm 0.01$ & $0.48 \pm 0.05$ \\
$D_{7.5}$ & $1.09 \pm 0.15^{\circ}$ & & $0.49 \pm 0.05$ \\
$W D_{7.5}$ & $0.68 \pm 0.48$ & $0.64 \pm 0.36$ & \\
\hline
\end{tabular}

a The value was significant in $r_{g}$ using a threshold of \pm 2 standard errors.

Table 4. - Maternal GCA $\left(G C A_{\mathrm{F}}\right)$, female GHA $\left(G H A_{\mathrm{F}}\right)$ and male $G H A\left(G H A_{\mathrm{M}}\right)$ estimates for $H_{7.5}, D_{7.5}$ and $W D_{7.5}$.

\begin{tabular}{|c|c|c|c|c|c|c|c|c|c|c|}
\hline \multirow[b]{2}{*}{ Female } & \multicolumn{3}{|l|}{$G C A_{r}$} & \multicolumn{3}{|l|}{$G H A_{\mathrm{r}}$} & \multirow[b]{2}{*}{ Male } & \multicolumn{3}{|l|}{$G H A_{\mathrm{M}}$} \\
\hline & $\begin{array}{l}H_{7.5} \\
(\mathrm{~m}) \\
\end{array}$ & $\begin{array}{l}D_{7.5} \\
(\mathrm{~cm}) \\
\end{array}$ & $\begin{array}{l}W D_{7.5} \\
\left(10^{\lrcorner}\right) \\
\end{array}$ & $\begin{array}{l}H_{7.5} \\
(\mathrm{~m}) \\
\end{array}$ & $\begin{array}{l}D_{7.5} \\
(\mathrm{~cm}) \\
\end{array}$ & $\begin{array}{l}W D_{7.5} \\
(\%)\end{array}$ & & $\begin{array}{l}H_{75} \\
(\mathrm{~m}) \\
\end{array}$ & $\begin{array}{l}D_{7.5} \\
(\mathrm{~cm}) \\
\end{array}$ & $\begin{array}{l}W D_{7.5} \\
\left(10^{\lrcorner}\right) \\
\end{array}$ \\
\hline UX-01 & 0.39 & 0.16 & 0.07 & $-1.50^{* * *}$ & $-1.34 * *$ & $-0.17^{*}$ & T25-08 & $0.83 *$ & $1.58^{* *}$ & 0.11 \\
\hline UX-30 & -0.17 & -0.41 & -0.08 & 0.10 & 0.54 & 0.11 & T25-09 & -0.05 & 0.15 & -0.07 \\
\hline U32-23 & 0.38 & 0.69 & $0.27^{*}$ & 0.97 & $1.06^{\circ}$ & -0.10 & $\mathrm{~T} 25-10$ & -0.19 & -0.50 & -0.03 \\
\hline U31-38 & $2.05^{*}$ & $2.17 *$ & 0.10 & 0.20 & 0.47 & -0.04 & T25-11 & -0.04 & -0.13 & 0.02 \\
\hline U89-16 & $-1.95^{*}$ & $-1.92^{*}$ & $-0.31^{*}$ & -0.04 & -0.43 & 0.09 & T25-12 & 0.20 & -0.01 & 0.01 \\
\hline UX-20 & $-2.09^{*}$ & $-2.19^{*}$ & 0.09 & $-1.29 *$ & $-1.43^{* *}$ & -0.02 & T43-01 & -0.45 & -0.51 & -0.06 \\
\hline UX-07 & 0.91 & 1.18 & 0.01 & $1.00^{*}$ & 0.74 & -0.02 & T44-20 & -0.02 & -0.19 & -0.12 \\
\hline UX-04 & -0.94 & -0.98 & 0.04 & -0.26 & -0.26 & 0.14 & T60-09 & 0.22 & 0.47 & 0.07 \\
\hline $\mathrm{UX}-02$ & 0.66 & 0.64 & -0.12 & 0.42 & 0.29 & -0.03 & TX-04 & -0.03 & -0.04 & 0.10 \\
\hline U31-4I & 0.76 & 0.66 & -0.07 & 0.40 & 0.42 & 0.04 & T43-31 & -0.47 & -0.83 & -0.03 \\
\hline
\end{tabular}

$*$, ** and *** Significant at $0.05,0.01$ and 0.001 levels, respectively. 
whilst the OP families demonstrated a slightly higher $C V$ in $W D_{7.5}$.

\section{Variance, $h^{2}$ and $d^{2}$ estimates}

The combined ANOVA analyses over two environments indicated significant differences in all traits among genotypes and between environments for the hybrids (Table 2 ), suggesting the diversity of the genotypes and their variability in environmental response. The GHA variances due to either female or male parents were also significant for all traits with a relatively high magnitude as compared to those of $S H A$, although $S H A$ variances were significant for majority of the traits. It appears that additive gene effects are more important in explaining phenotypic variations of growth and wood density in the $E$. urophylla $\times E$. tereticornis population while the significance of dominant gene effects declines in growth with time. Moreover, the GHA mean squares due to the females were considerably larger than those of the males, though it was uncertain to what extent this difference was genetically meaningful. Furthermore, the interaction between genotype and environment varied with trait, e.g. significant $G H A_{\mathrm{F}} \times$ environment interaction for growth over ages 1.5 and 2 but non-significant $G H A_{\mathrm{M}}$

Table 5. - Parental SHA estimates for $H_{7.5}, D_{7.5}$ and $W D_{7.5}$.

\begin{tabular}{|c|c|c|c|c|c|c|c|c|c|}
\hline \multirow[b]{2}{*}{ Female } & \multirow[b]{2}{*}{ Male } & \multicolumn{3}{|l|}{$S H A$} & \multirow[b]{2}{*}{ Female } & \multirow[b]{2}{*}{ Male } & \multicolumn{3}{|l|}{$S H A$} \\
\hline & & $\begin{array}{l}H_{7.5} \\
(\mathrm{~m})\end{array}$ & $\begin{array}{l}D_{7.5} \\
(\mathrm{~cm})\end{array}$ & $\begin{array}{l}W D_{7.5} \\
\left(10^{-1}\right)\end{array}$ & & & $\begin{array}{l}H_{7.5} \\
(\mathrm{~m})\end{array}$ & $\begin{array}{l}D_{7.5} \\
(\mathrm{~cm})\end{array}$ & $\begin{array}{l}W D_{7.5} \\
\left(10^{-1}\right)\end{array}$ \\
\hline \multirow[t]{10}{*}{ UX-01 } & T25-08 & -0.36 & 0.03 & 0.02 & \multirow[t]{7}{*}{ U89-16 } & $\mathrm{T} 25-08$ & 1.15 & 1.49 & 0.12 \\
\hline & $\mathrm{T} 25-09$ & $-0,42$ & -0.21 & -0.06 & & T25-09 & 0.86 & 0.86 & 0.22 \\
\hline & T25-10 & $-1.75^{*}$ & $-1.85^{*}$ & -0.22 & & $\mathrm{~T} 25-10$ & -0.62 & -0.91 & 0.02 \\
\hline & $\mathrm{T} 25-11$ & -0.37 & -0.95 & -0.14 & & $\mathrm{~T} 25-11$ & -0.60 & -1.24 & 0.01 \\
\hline & T25- 12 & -0.41 & -0.69 & -0.04 & & T25-12 & 0.90 & 1.42 & -0.05 \\
\hline & T43-01 & -1.50 & -0.78 & -0.16 & & $\mathrm{~T} 44-20$ & 0.02 & -0.49 & 0.09 \\
\hline & T44-20 & -1.03 & -0.60 & -0.17 & & T43-31 & -0.69 & -1.39 & 0.11 \\
\hline & $\mathrm{T} 60-09$ & -1.65 & -1.54 & -0.14 & \multirow[t]{3}{*}{$\mathrm{UX}-20$} & T25-08 & -0.31 & -0.01 & 0.12 \\
\hline & TX-04 & -0.95 & -1.25 & -0.04 & & T25-09 & -0.78 & -0.93 & -0.13 \\
\hline & T43-31 & -0.09 & -0.51 & -0.08 & & $\mathrm{~T} 25-10$ & -0.68 & -1.15 & 0.04 \\
\hline \multirow[t]{6}{*}{ UX-30 } & T25-09 & -0.58 & 0.11 & -0.08 & & T25-11 & -0.49 & -0.64 & 0.06 \\
\hline & $\mathrm{T} 25-11$ & 0.44 & 0.96 & 0.19 & & $\mathrm{~T} 25-12$ & -0.53 & -1.06 & 0.10 \\
\hline & T43-01 & -0.67 & -1.19 & -0.09 & & T43-01 & $-1.90 *$ & $-2.06^{*}$ & -0.13 \\
\hline & $\mathrm{T} 44-20$ & 0.76 & 0.49 & 0.05 & & $\mathrm{~T} 44-20$ & 0.12 & 0.09 & 0.04 \\
\hline & T60-09 & -0.16 & 0.94 & 0.17 & & T43-31 & -1.62 & -1.66 & -0.18 \\
\hline & TX-04 & 0.59 & 0.92 & $0.30^{*}$ & UX-07 & T25-08 & $2.79 *$ & $2.76^{* * *}$ & 0.12 \\
\hline \multirow[t]{7}{*}{ U32-23 } & T25-08 & 1.18 & $1.89^{*}$ & 0.13 & & T25-09 & -0.08 & 0.18 & -0.20 \\
\hline & T25-09 & 0.84 & 1.03 & -0.03 & & $\mathrm{~T} 25-10$ & 1.43 & 1.01 & 0.03 \\
\hline & $\mathrm{T} 25-12$ & 1.34 & 1.25 & -0.03 & & $\mathrm{~T} 25-11$ & 0.30 & 0.67 & 0.07 \\
\hline & $\mathrm{T} 44-20$ & -0.04 & -0.13 & -0.19 & & T25-12 & -0.01 & -0.55 & -0.06 \\
\hline & T60-09 & $1.85^{*}$ & $1.98^{*}$ & 0.15 & & T43-01 & 0.24 & -0.12 & 0.06 \\
\hline & TX-04 & 0.08 & 0.55 & $-0.24^{*}$ & & $\mathrm{~T} 44-20$ & 0.91 & 0.67 & -0.14 \\
\hline & T43-31 & 0.06 & -0.17 & -0.18 & & T60-09 & 1.12 & 0.70 & 0.07 \\
\hline \multirow[t]{4}{*}{ U31-38 } & $\mathrm{T} 43-01$ & 0.73 & 1.22 & -0.09 & & $\mathrm{~T} 43-31$ & -0.20 & 0.10 & 0.02 \\
\hline & T44-20 & -0.82 & -0.85 & $-0.32^{*}$ & UX-04 & T25-09 & -0.22 & -0.14 & -0.01 \\
\hline & T60-09 & 0.70 & 1.03 & 0.06 & & T43-01 & -0.65 & -0.44 & 0.15 \\
\hline & TX-04 & 0.11 & 0.23 & $0.27 *$ & & TX-04 & 0.42 & 0.41 & 0.21 \\
\hline \multirow[t]{3}{*}{ U31-41 } & T43-01 & 0.53 & 0.46 & 0.04 & & $\mathrm{~T} 43-31$ & -0.30 & -0.70 & 0.18 \\
\hline & T43-31 & -0.07 & -0.18 & 0.06 & UX-02 & $\mathrm{T} 44-20$ & 0.50 & 0.30 & -0.13 \\
\hline & & & & & & T60-099 & 0.59 & 0.65 & 0.06 \\
\hline
\end{tabular}

*,** and *** Significant at $0.05,0.01$ and 0.001 levels, respectively. 
or $S H A \times$ environment for most traits. Additionally, for the maternal OP families, significant differences were found among families in all the traits as well as between environments in $W D_{7.5}$ and growth over ages 0.5-4 except for $H_{1.5}$ and $D_{4}$ (data not shown).

The narrow-sense heritability $\left(h^{2}\right)$ estimates with hybrid growth and wood density ranged between $0.07 \pm 0.05\left(H_{0.5}\right)$ and $0.17 \pm 0.07\left(H_{7.5}\right)$ over the different ages (Table 2), suggesting that both growth and wood density were under a low level of additive genetic control. The $d^{2}$ estimates for both trait types were also small, with the lowest $0.02 \pm 0.05$ in $D_{7.5}$ and the highest $0.23 \pm 0.10$ in $H_{1.5}$, suggesting a weak effect of dominance on these traits. It seems that growth has an increasing $h^{2}$ with advancing age while a reverse trend holds true for $d^{2}$. In addition, $h^{2}$ values estimated from the OP families were markedly larger than those of hybrids, ranging from 0.22 in $H_{4}$ to 0.70 in $H_{1.5}$ (data not shown).

\section{Phenotypic and additive genetic correlations}

Additive genetic correlations of $H_{7.5}$ and $D_{7.5}$ with $W D_{7.5}$ for the hybrid population across the two environments were $0.68 \pm 0.48$ and $0.64 \pm 0.36$, respectively, which were non-significant using a threshold of \pm 2 standard errors, though phenotypic correlations were moderately strong and positive (Table 3). The non-significant genetic correlations may suggest that selection in one trait is unlikely to have any effect on the hybrid performance in the alternative trait. Additionally, there were very strong phenotypic and genetic correlations either between $H$ and $D$ at a specific age or between ages for a given growth trait $H$ or $D$ (data not shown).

\section{Maternal GCA, parental GHA and SHA estimates}

Maternal GCA, parental GHA and SHA effects were estimated for growth and wood density only at age 7.5 (Tables 4 and 5). The females U32-23 and UX-07 and male T25-08 were the best general combiners for $H_{7.5}$ and/or $D_{7.5}$ with highly significant positive $G H A$ effects. For $W D_{7.5}$, the females UX-04 and UX-30 and males T25-08 and TX-04 exhibited GHA effects no less than $0.10\left(10^{-1}\right)$ though no $G H A$ effect was positively significant. When overall hybridizing ability for both growth and wood density was considered, female UX-30 and male T25-08 appeared to be good combiners in improving both types of traits. In addition, maternal GCA effect was not necessarily a good indicator of $G H A$, e.g. the correlations between GCA and GHA being 0.48 $(P=0.17), 0.65(P=0.04)$ and $-0.56(P=0.10)$ for $H_{7.5}, D_{7.5}$ and $W D_{7.5}$, respectively.

For $H_{7.5}$ and $D_{7.5}$, the combination UX-07 $\times$ T25-08 had the highest $S H A$ values $(2.79 \mathrm{~m}$ and $2.76 \mathrm{~cm}$, respectively; Table 5) and also provided the best growth performance $(20.98 \mathrm{~m}$ and $17.79 \mathrm{~cm}$, respectively; Table 6). For wood density $W D_{7.5}$, UX-30 $\times$ TX-04 and U31-38 $\times$ TX-04 had the highest SHA values [0.30 and $0.27\left(10^{-1}\right)$, respectively; Table 5] as well as the highest overall values in this trait $\left[4.48\right.$ and $4.54\left(10^{-1}\right)$, respectively].

Table 6. - The best five hybrids in female-parent heterosis $(F P H)$ for $H_{7.5}, D_{7.5}$ and $W D_{7.5}$.

\begin{tabular}{|c|c|c|c|c|c|}
\hline Trait & Rank in $F P H$ & Hybrid & MeantSD & $A F P H$ & $R F P H(\%)$ \\
\hline \multirow[t]{5}{*}{$H_{7.5}(\mathrm{~m})$} & 1 & $\mathrm{U} 89-16 \times \mathrm{T} 25-08$ & $17.54 \pm 3.88$ & 6.24 & 42.2 \\
\hline & 2 & U $89-16 \times \mathrm{T} 25-09$ & $16.85 \pm 4.12$ & 5.56 & 37.6 \\
\hline & 3 & $\mathrm{UX}-07 \times \mathrm{T} 25-08$ & $20.98 \pm 1.95$ & 5.46 & 36.9 \\
\hline & 4 & $\mathrm{U} 89-16 \times \mathrm{T} 44-20$ & $16.12 \pm 3.88$ & 4.82 & 32.6 \\
\hline & 5 & $\mathrm{UX}-20 \times \mathrm{T} 44-20$ & $16.36 \pm 3.70$ & 4.78 & 32.3 \\
\hline \multirow[t]{5}{*}{$D_{7.5}(\mathrm{~cm})$} & 1 & $\mathrm{U} 89-16 \times \mathrm{T} 25-08$ & $14.62 \pm 4.75$ & 5.49 & 47.2 \\
\hline & 2 & $\mathrm{UX}-07 \times \mathrm{T} 25-08$ & $17.79 \pm 3.54$ & 4.92 & 42.2 \\
\hline & 3 & $\mathrm{UX}-30 \times \mathrm{TX}-04$ & $14.48 \pm 5.04$ & 4.27 & 36.7 \\
\hline & 4 & $\mathrm{U} 89-16 \times \mathrm{T} 25-12$ & $13.30 \pm 4.82$ & 4.18 & 35.9 \\
\hline & 5 & UX-30 $\times$ T60-09 & $14.38 \pm 4.84$ & 4.18 & 35.9 \\
\hline \multirow[t]{5}{*}{$W D_{7.5}\left(10^{1}\right)$} & 1 & $\mathrm{U} 89-16 \times \mathrm{T} 25-12$ & $4.33 \pm 0.32$ & 0.82 & 22.0 \\
\hline & 2 & $\mathrm{U} 89-16 \times \mathrm{T} 43-31$ & $4.31 \pm 0.49$ & 0.81 & 21.7 \\
\hline & 3 & $\mathrm{U} 89-16 \times \mathrm{T} 25-10$ & $4.27 \pm 0.71$ & 0.77 & 20.6 \\
\hline & 4 & U89-16 × T25-08 & $4.27 \pm 0.56$ & 0.77 & 20.5 \\
\hline & 5 & $\mathrm{UX}-30 \times \mathrm{TX}-04$ & $4.48 \pm 1.03$ & 0.76 & 20.2 \\
\hline
\end{tabular}

$A F P H$, absolute female-parent heterosis; $R F P H$, relative female-parent heterosis. 


\section{Heterosis}

The female-parent heterosis $(F P H)$ of each hybrid was estimated for growth and wood density at age 7.5. The magnitude of heterosis varied with trait and hybrid. The best five hybrids in $F P H$ for $H_{7.5}, D_{7.5}$ and $W D_{7.5}$ are shown in Table 6. Compared with maternal OP families, 45, 48 and 37 hybrids showed positive $F P H$ estimates for $H_{7.5}, D_{7.5}$ and $W D_{7.5}$ (data not shown), with the highest relative FPH (RFPH) being $42.2 \%$ $(\mathrm{U} 89-16 \times \mathrm{T} 25-08), 47.2 \%(\mathrm{U} 89-16 \times \mathrm{T} 25-08)$ and $22.0 \%$ (U89-16 $\times$ T25-12), respectively. On average, the $F P H$ values observed were all positive, being $1.64 \mathrm{~m}$ (RFPH $11.1 \%), 1.50 \mathrm{~cm}(12.8 \%)$ and $0.12\left(10^{-1} ; 3.0 \%\right)$ for $H_{7.5}, D_{7.5}$ and $W D_{7.5}$, respectively.

\section{Discussion}

The generally better performance of $E$. urophylla $\times$ $E$. tereticornis hybrids relative to $E$. urophylla purespecies OP progeny, along with the relatively large number of female-parent heterotic hybrids, could provide evidence for heterosis even between inter-sectional species. Further, E. urophylla $\times E$. tereticornis hybrids are easy to propagate vegetatively, especially through tissue culture (LIU and WANG, 2005). These will therefore warrant the efforts in hybrid breeding with respect to heterosis exploitation and genetic gain realization.

The contrasting comparison of hybrid performance between the two environments may be a reflection of the difference in adaption between the two population types. $E$. urophylla $\times E$. tereticornis hybrids are usually more cold tolerant and adaptive to the cold winter besides favorable rainfall and soil conditions in Yong'an, whereas $E$. urophylla OP families exhibited rapid growth in low-latitude regions (ELDRIDGE et al., 1993) and could be more competitive at the warm but less fertile site of Changtai. Also, such an environmental difference, coupled with significant hybrid $\times$ environment interaction at most ages, may indicate essentially that the expression of hybrid superiority is often highly dependent on the environmental conditions which may limit performance of one or other of the pure-species parents (PоTтs and Dungey, 2004). Similarly, Malan and VERRYN (1996) noticed environmental sensitivity of $E$. grandis derived hybrids in wood properties, and LEE et al. (2001) observed marked environmental variation in survival and growth of eucalypt hybrids. Climatic and edaphic conditions of the local environment as well as adaptability of hybrids are most likely to account for such differences. This may also evoke the necessity of multiple environments for comprehensive assessment of hybrid performance and for reliable estimation of genetic parameters.

The $h^{2}$ and $d^{2}$ estimates for hybrid growth are within the low range as compared to earlier reports with interspecific hybrids in Eucalyptus. Bouvet and Vigneron (1995) observed $h^{2}$ of 0.00 to 0.45 for $H$ and $D$ up to 48 months in $E$. urophylla $\times E$. grandis and $E$. urophylla $\times$ E. pellita F. MuELL. GAN et al. (2004) obtained $h^{2}$ values ranging from 0.34 to 0.41 for 5 -year-old $H$ and $D$ in $E$. urophylla $\times E$. tereticornis, $E$. urophylla $\times E$. camaldulensis DEHNH. and E. urophylla $\times E$. pellita. VOLKER et al. (2008) reported $h^{2}$ of $0.42-0.61$ and $d^{2} 0.00-0.52$ for $D$ measured at one site over ages 2 to $10 \mathrm{in} E$. nitens $\times E$. globulus. These authors used only single-site data, in which the additive and dominant genetic effects would include the site factors and therefore be inflated, as evidenced by multiple-location trials of $E$. grandis $\times$ $E$. tereticornis and $E$. grandis $\times E$. camaldulensis hybrids (MADHIBHA et al., 2013). Nevertheless, the relatively stable $h^{2}$ values over ages are in accordance with the results obtained from hybrids of $E$. nitens $\times E$. globulus (VolKer et al., 2008), E. urophylla $\times E$. grandis (Bouvet and Vigneron, 1995; RETIEF and STANGER, $2009), E$. grandis $\times E$. tereticornis and $E$. grandis $\times$ E. camaldulensis (MADHIBHA et al., 2013). Moreover, the $h^{2}$ and $d^{2}$ estimates for hybrid wood density are comparable to previous reports, e.g. $h^{2} 0.20$ and $d^{2} 0.02$ for Pilodyn-based wood density on one site at age 6 in $E$. nitens $\times E$. globulus (VOLKER et al., 2008), and the non-significant interaction of genotype by environment identified in the present study might partially explain such a comparability even with different number of trial sites.

Given that the estimates of additive genetic variance in pure-species and hybrid populations are not theoretically comparable (GORDON, 1999), $h^{2}$ values derived here from hybrid populations could have limited usages in prediction of hybrid performance and genetic gains following a classical quantitative genetic model. Alternatively, the generally low correlations between GCA and GHA would suggest that pure-species breeding values are not useful for identifying parents that produce hybrids with faster growth and higher wood density. By comparison, VolKER et al. (2008) observed in E. nitens $\times$ $E$. globulus similar correlations between maternal GCA and GHA in diameter (0.35-0.69 across ages) but a considerably higher correlation in wood density (0.68 at age 6 ). Nonetheless, the significant correlation between $G C A$ and $G H A$ for $D_{7.5}(0.65 ; P=0.04)$ may indicate that pure-species selection prior to hybridization, at least for maternal $E$. urophylla, would be efficient in producing outstanding hybrids for diameter trait rather than height and wood density.

The positive $F P H$ values verified with $E$. urophylla $\times$ $E$. tereticornis would suggest hybrid superiority or heterosis for inter-sectional combination of species with so large geographic and genetic distance. However, outbreeding depression or hybrid abnormality has been observed frequently in eucalypts, particularly for species from the section Maindenaria (POTTS and DUNGEY, 2004; Volker et al., 2008; Costa E Silva et al., 2012). Thus, it seems that heterosis may arise between certain species regardless of their origin from the same or different sections. However, it should be noted that such superiority may be combination specific as there are still some inferior hybrids, which could involve the best parents.

The usefulness of the hybrid superiority has to be carefully considered as it is unlikely to deploy the superior hybrids through a seed orchard strategy when clonal forestry has been largely preferred for those species and hybrids amenable to mass vegetative propagation. Clonal deployment of the elite individuals from the superior hybrids may be an option, but their vegetative 
propagation ability and their propagule (ramet) performance have to be tested. YU et al. (2011) have identified different quantitative trait loci (QTLs) controlling growth and rooting ability in $E$. urophylla $\times E$. tereticornis hybrids, suggesting the difference in genes responsible for the two types of traits. Alternatively, such elite individuals could be applied to further hybridization to produce next-generation hybrids, but the operational potential has to be explored as severe depression may occur in $\mathrm{F}_{2}$ hybrids (CosTA E SILVA et al., 2012).

In conclusion, the significant effects of GHA and SHA and the sound number of heterotic hybrids imply that selection of parents for hybridizing ability and heterosis has a potential to increase growth and wood density in $E$. urophylla $\times E$. tereticornis hybrid breeding.

\section{Acknowledgments}

This work was supported by the Ministry of Finance of China (RITFKYYW2010-04) and the Ministry of Science and Technology of China (2011AA100202 and 2012CB114505). The authors thank KUNMING WU and JUYING WU for kind assistance in control pollination and seedling raising as well as JiAnwen Li, SHuzHong Li, WeNGe Lin, CHANGFu HoNG and BINGNAN WANG for valuable cooperation in field trial establishment and maintenance. We appreciate highly the help of ZHAOYUAN ZHANG and YONG GUO in field measurement.

\section{References}

Bouffier, L., C. Charlot, A. Paffin, P. Rozenberg and A. Kremer (2008): Can wood density be efficiently selected at early stage in maritime pine (Pinus pinaster Ait.)? Ann For Sci 65: 106p1-106p8.

Bouvet, J. M. and P. Vigneron (1995): Age trends in variances and heritabilities in Eucalyptus factorial mating designs. Silvae Genet 44: 206-216.

Brooker, M. I. H. (2000): A new classification of the genus Eucalyptus L'Hér. (Myrtaceae). Aust Syst Bot 13: 79-148.

BuEREN, M. VAN (2004): Eucalypt tree improvement in China. Impact assessment series report No. 30. Australian Centre for International Agricultural Research, Canberra.

Costa e Silva, J., B. M. Potts and P. Tilyard (2012): Epistasis causes outbreeding depression in eucalypt hybrids. Tree Genet Genomes 8: 249-265.

DiAnese, J. C. and M. C. G. DRISTIG (1993): Screening Eucalyptus selections for resistance to bacterial wilt caused by Pseudomonas solanacearum, pp. 206-218. In: Bacterial wilt, ACIAR Proceedings No. 45, edited by G. L. Hartman and A. C. HaYward, Australian Centre for International Agricultural Research, Canberra.

EldRIDGe, K. G., J. DAVIDSON, C. HARDwOod and G. VAN WYK (1993): Eucalypt domestication and breeding. Oxford University Press, Oxford.

GAN, S., M. LI, F. LI, K. WU, J. WU and J. BAI (2004): Genetic analysis of growth and susceptibility to bacterial wilt (Ralstonia solanacearum) in Eucalyptus by interspecific factorial crossing. Silvae Genet 53: 254-258.

GoRDON, I. L. (1999): Quantitative genetics of intraspecies hybrids. Heredity 83: 757-764.
Griffin, A. R., I. P. Burgess and L. Wolf (1988): Patterns of natural and manipulated hybridization in the genus Eucalyptus L'Herit - a review. Aust J Bot 36: 41-46.

Hallauer, A. R. and J. B. Miranda (1981): Quantitative genetics in maize breeding. Iowa State Univ. Press, Ames.

He, X., F. Li, M. Li, Q. Weng, J. ShI, X. Mo and S. GaN (2012a): Quantitative genetics of cold hardiness and growth in Eucalyptus as estimated from $E$. urophylla $\times$ E. tereticornis hybrids. New For 43: 383-394.

He, X., Y. WANG, F. LI, Q. Weng, M. LI, L. Xu, J. ShI and S. GAN (2012b): Development of 198 novel EST-derived microsatellites in Eucalyptus (Myrtaceae). Am J Bot 99: e134-e148.

Holland, J. B. (2006) Estimating genotypic correlations and their standard errors using multivariate restricted maximum likelihood estimation with SAS Proc Mixed. Crop Sci 46: 642-654.

IsIK, F. and B. Li (2003): Rapid assessment of wood density of live trees using the Resistograph for selection in tree improvement programs. Can J For Res 33: 2426-2435.

LeE, D. J., D. G. NikLes and G. R. Dickinson (2001): Prospects of eucalypt species, including interspecific hybrids from South Africa, for hardwood plantations in marginal subtropical environments in Queensland, Australia. South Afr For J 190: 89-94.

LIN, M. and B. LI (2003): The study on introduction of cold tolerant Eucalyptus in Hunan. Eucalypt Sci Technol 20: $1-12$.

LiU, Y. and D. WANG (2005): Rapid propagation of Eucalyptus urophylla $\times E$. tereticornis cv M1 by tissue culture. J Southwest Agri Univ (Nat Sci) 27: 237-239.

LYNCH, M. and B. WALSH (1998): Genetics and analysis of quantitative traits. Sinauer Associates Inc., Sunderland, Massachusetts.

Madhibha, T., R. Murepa, C. Musokonyi and W. Gapare (2013): Genetic parameter estimates for interspecific Eucalyptus hybrids and implications for hybrid breeding strategy. New For 44: 63-84.

MALAN, F. S. and S. D. VERRYN (1996): Effect of genotype-by-environment interaction on the wood properties and qualities of four-year-old Eucalyptus grandis and $E$. grandis hybrids. South Afr For J 176: 47-53.

MARCAR, N. E. (1989): Salt tolerance of frost-resistant eucalypts. New For 3: 141-149.

MARTIN, B. (1989): The benefits of hybridization. How do you breed for it? pp. 79-92. In: Breeding tropical trees, edited by G. L. Gibson, A. R. Griffin and A. C. Matheson, Oxford Forestry Institute, Oxford.

Meddings, R. L. A., J. A. McComb and D. T. BeLl (2001): The salt-water-logging tolerance of Eucalyptus camaldulensis $\times E$. globulus hybrids. Aust J Exp Agr 41: 787-792.

Melchinger, A. E. and R. K. Gumber (1998) Overview of heterosis and heterotic groups in agronomic crops, pp. 29-44. In: Concepts and breeding of heterosis in crop plants, edited by K. R. LAMKEY and J. E. StAub, CSSA, Madison, Wisconsin.

NikLES, D. G. and R. S. Newton (1991): Correlations of breeding values in pure and hybrid populations of hoop pine and some southern pines in Queensland and relevance to breeding strategies, pp. 192-196. In: Proceedings of the $11^{\text {th }}$ meeting of RWG 1 (Forest Genetics), edited by C. A. Dean, CSIRO, Canberra. 